\title{
DE FÖRSTA RENÄSSANSMUSEERNA I ROM OCH FLORENS
}

Lennart Palmqvist

I april 1485 gjordes en arkeologisk upptäckt som satte hela det humanistiska etablissemanget $i$ Rom i gungning, eftersom den för en tid gav konkret form àt de kulturella förväntningar som gruppen av entusiastiska antikbeundrare hade: I närheten av Via Appia på en plats som inte utan anledning kallades fondo statuario, fann några lombardiska murare en sarkofag innehållande kroppen av en ung flicka, mirakulöst välbevarad. "... i en marmorsarkofag hittades liket av en flicka, som varken saknade näsa eller panna, varken läppar, tänder eller tunga och vars här var särskilt framträdande eftersom köttet torkat under de 1700 år sarkofagen legat i jorden..." ' Det bestämdes omedelbart att sarkofagen med innehäll skulle transporteras till Campidoglio och ställas ut al pubblico på Konservatorspalatsets gård.

Kroppen av den unga kvinnan, insmord med en blandning av balsam, cederolja och terpentin, gjorde ett djupt intryck på besökarna och man började till och med försöka gissa vem det kunde vara. Humanisten och antikvarien Pomponius Leto föreslog att det kunde röra sig om Ciceros dotter Tullia. Entusiasmen över upptäckten spred sig till hela Roms befolkning och det blev en veritabel massvandring upp till Kapitolium. Men allt detta varade endast några dagar, kontakten med luften var katastrofal: kroppen började svartna och ruttna och påven Innocentius VIII beslöt att det var dags att åter begrava liket.

Händelsen gav upphov till åtskilliga kommentarer och beskrivningar bland de lärde i Rom. Jag vill här försöka ge en bakgrund till hur det kunde komma sig att Kapitolium och Konservatorspalatset redan 1485 uppfattades som den naturliga och självklara platsen för att ställa ut ett arkeologiskt fynd för allmänheten. I motsats till den rådande uppfattningen bland museihistoriker att det historiska museet är ett 1800-talsfenomen, hävdar jag att det finns uppenbara skäl att betrakta Konservatorspalatset i Rom som ett historiskt museum redan från renässansen. ${ }^{2}$

\section{DEN IDÉHISTORISKA BAKGRUNDEN: HUMANISTERNA}

Samtidigt som renässanshumanisterna strävade efter att utveckla sin förståelse för 
4 de klassiska byggnadernas funktion och ursprung, accelererade förstörelsen av de till hälften begravda ruinerna i takt med den ökande byggnadsverksamhet som renässansen gav upphov till. Rom var en stad vars förflutna i materiell mening fullt ut stödde det nuvarande! I ett berömt brev till påve Leo X, skrivet på Rafaels begäran av vännen Baldassare Castiglione, beklagar konstnären sig över att så många monument och byggnader hade försvunnit till och med på den korta tid, mindre än tolv år, som han befunnit sig i Rom. Leo svarade med att göra Rafael till Roms överantikvarie och ge honom uppdraget att bygga Peterskyrkan och gav honom samtidigt instruktioner om att undvika onödig förstörelse. $^{3}$

Men hur ofta de antika ruinerna än plundrades av cavatori eller bebyggdes av kardinaler och påvar så var de alltför omfattande för att kunna ignoreras. De gigantiska mått, som det romerska imperiets byggnader ännu hade, kontrasterade skarpt mot den medeltida by som Rom hade blivit. Deras närvaro utgjorde en otvetydig påminnelse om samtidens kraftlöshet $\mathrm{i}$ jämförelse med den antika epokens storslagenhet. Samtidigt antydde deras förstörelse att man inte enbart kunde lita till människans prestationer för att motstå tidens förgänglighet.

Denna litet nostalgiska och moraliserande stämning utmärker öppningssidorna i Poggio Bracciolinis De varietate fortunae - en dialog om lyckans växlingar som påbörjades 1431 och överlämnades till påve Nicolas V år 1448. Poggio rider runt till häst bland ruinerna tillsammans med en kollega från det påvliga sekretariatet och lamenterar över hur det gyllene Rom, som till exempel Vergilius beskrivit det, förfallit till oigenkännlighet även för stadens egna invånare. Den kapitolinska kullen, en gång centrum för det romerska imperiet inför vilket hela världen darrat, dit så många kejsare stigit upp i triumf, låg nu öde och förstörd.

Trots nostalgin och den stundtals moraliserande tonen innebär Poggios dialog något helt nytt: han inkluderar nämligen detaljerade beskrivningar av antika tempel, bad, triumfbågar, pyramider, teatrar, amfiteatrar, portar och andra klassiska monument. Viktigt är också att han lämnar den magiska och fantastiska attityd som utmärker de medeltida Mirabiliabeskrivningarna av sällsamheter i Rom. Istället betraktar han ruinerna som viktiga spår av en förgången civilisation, sedan länge bortglömd men möjlig att återupptäcka genom antikvarisk undersökning.

I det syftet inkorporerade han två nya metoder i sitt arbete, dels ett noggrannare användande av klassiska texter som till exempel Frontinus skrift De aquis Urbis Romae (han hade själv återfunnit ett manuskript till Frontinus arbete i klostret Montecassino). Poggios andra metod gick ut på att använda sig av det epigrafiska materialet. Han hade börjat sammanställa en volym med inskrifter, som han kopierade från antika monument, och han uttrycker förvåning över att Petrarca kunde vara så påverkad av folkliga föreställningar att han trodde att pyramiden vid Porta Ostiense var Remus grav, när den anbragda inskriften tydligt berättade att den tillhörde den romerske köpmannen Cestius. ${ }^{4}$ Genom sådan flit blev Poggio en pionjär när det gällde att på ett historiskt korrekt sätt kartlägga den antika stadens topografiska verklighet. 


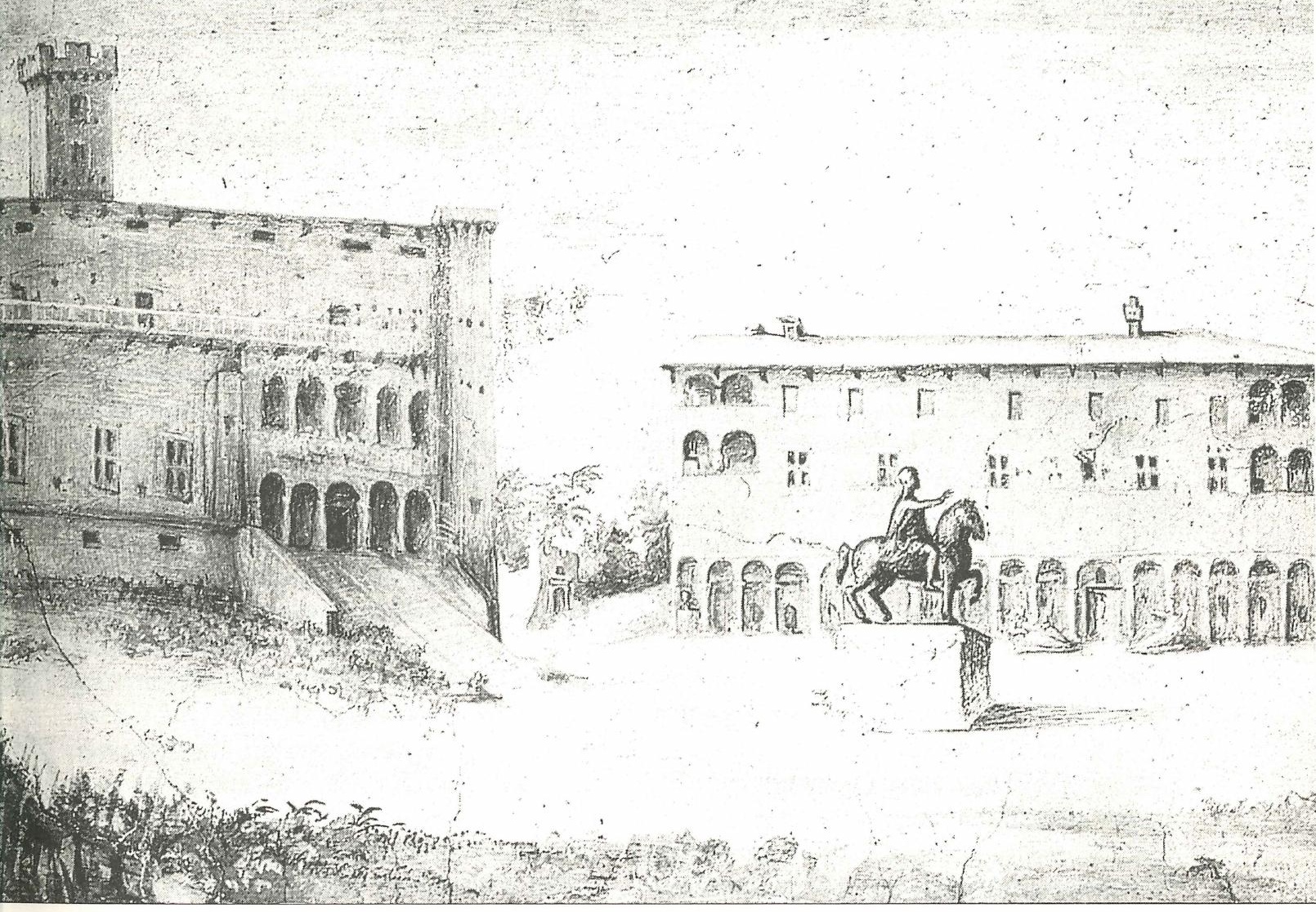

Kapitolium med senatorspalatset, konservatorspalatset och Marcus Aureliusstatyn. Teckning av Martin van Hemskerk omkring 1537. (Berlin, Kupferstichkabinett).

\section{BESKRIVNING OCH INSAMLANDE AV KULTURARVET}

När Eugenius IV återvände till Rom efter nästan tio års bortovaro år 1443 flyttade Poggios kollega, Flavio Biondo, också till Rom och blev den mest passionerade utforskaren av det antika Rom i mitten av århundradet. För honom representerade Roms ruiner inte endast en förstörd civilisation, utan också ett ovärderligt källmaterial för att återerövra den antika romerska kulturen och dess historia. Han uttryckte detta i sin bok Roma instaurata påbörjad 1446. Vad som fick honom att skriva detta verk var, som han säger i förordet, att han insåg att det inte endast var den okunniga massan utan även de s. k. lärde som skymfade lämningarna av de klassiska byggnaderna med falska och barbariska namn. Resultatet var allvarligt, hävdade han, eftersom dolt i dessa strukturer fanns det Rom som en gång varit «beskyddare av snille, dygdernas förebild, modell för berömmelse och ära etc. kort sagt ursprunget till allt det goda i denna världen».

Arkeologi blev nyckeln till det humanistiska företaget att återfå det antika Roms visdom och kraft. Avgörande för arkeologin var korrekt identifikation och klassifikation av de antika byggnaderna. Det som utgör kärnan i Biondos arbete är en ämnesmässigt ordnad beskrivning av portar, obelisker, bad, teatrar, amfiteatrar, cirkusar, kolonner och andra monument, där hans ambition inte endast är att beskriva och identifiera dem, utan också att förklara deras funktion; när han diskuterar teaterns arkitektoniska utformning går han också igenom de viktigaste elementen i den klassiska utformningen av tragedin, komedin och pantomimen.

Biondo gick igenom alla klassiska texter för referenser till romersk topografi, men 
6 företog själv inte någon arkeologisk utgrävning - det gjorde inte någon renässansarkeolog. Han var dock mottaglig för nya upptäckter som framkom genom byggnadsverksamhet eller på annat sätt. Till exempel upptäckten av Pompejusteatern.

Metodologiskt var Biondo ett föredöme långt in på 1600-talet och många humanister fortsatte hans arbete bland annat genom att systematiskt samla inskrifter. I Pomponius Letos Accademia Romana förenades en rad betydande konstnärer och andra intellektuella av sitt hängivna intresse för den klassiska antiken och arkeologin. Att samla antika inskrifter, skulpturer, bronser, mynt, medaljer och gemmer blev en passion för renässanshumanisterna.

Påven Paul II visade sig vara en ivrig samlare. Men vid 1500-talets början fanns det knappast någon kultiverad kardinal som inte dekorerade sin trädgård med antika skulpturer eller sitt arbetsrum med andra passande antikviteter. På en nivå representerar sådant samlande endast den fashionabla smaken, på en annan visar det också en insikt om dessa föremåls autenticitet som källor till kunskap om den klassiska kulturen. Mynt fungerade som hjälp vid identifiering av skulpturer och redan vid 1500-talets början var numismatik och epigrafik självständiga discipliner.

En annan påvlig sekreterare var Leon Battista Alberti; liksom Biondo och Poggio kom han till Kurian i Rom 1443. Albertis utvecklade förståelse av funktionen och formgivningen av Roms klassiska byggnader utgick från hans studium av Vitruvius De architectura, vars text Poggio hade återfunnit under sina resor i Schweiz år 1414. Även om Vitruvius inte hade varit helt okänd under medeltiden, så blev hans arkitekturteori förstådd på allvar först av Alberti, som både var utövande arkitekt och samtidigt kunde studera de existerande monumenten i Rom. Dessutom nöjde sig Alberti inte bara med att förstå det antika Rom utan ville, liksom Biondo, restaurera staden. Resultatet blev De re aedificatoria som presenterades för Nicolas V år 1452.

Denna inställning, att se ruinerna $\mathrm{i}$ det antika Rom som källa både till estetiska värden och som konstruktionsmässiga förebilder till samtida byggnadsverksamhet, fortsatte med flera påvliga arkitekter som Bramante, Rafael och Giuliano Sangallo; den senare mätte upp Kolosseum år 1513.

Vid 1500-talets början hade tre generationer humanister, konstnärer och arkitekter - genom att kliva omkring bland ruinerna, mäta och teckna av, jämföra med relevanta texter och genom att använda sitt ackumulerade vetande fått fram en betydligt mer korrekt bild av Roms klassiska byggnader och monument. Baden uppfattades nu som bad och inte som palats. Kolosseum, som under medeltiden antagits vara ett tempel ${ }^{5}$, blev nu rätt uppfattad som en amfiteater. Ryttarstatyn i brons av Marcus Aurelius framför Lateranen, som medeltida romare varit övertygade om föreställt Konstantin, fick en rad nya identiteter tills den rätta kom fram på 1470-talet genom humanisten Platinas försorg.

De romerska humanisternas starka emfas på de tidlösa aspekterna av det antika Roms prestation stod i bjärt kontrast till den florentiska humanistiska traditionen. För florentinare som Leonardo Bruni och Nicolò Machiavelli var däremot en historisk analys av de politiska krafter som styrt utvecklingen $\mathrm{i}$ republikens Rom avgörande för att kunna härleda vilka 
lagar som styr politiskt beteende och för dem representerade republiken, inte den degenererade kejsartiden, höjdpunkten av Roms storhetstid. ${ }^{6}$ Macchiavellis historiesyn var starkt påverkad av de antika romerska historieskrivarna Livius och Polybios där republikens medborgaranda och medborgardygder var nödvändiga aspekter av det ideala samhället. Ur det perspektivet fanns ingen plats för något intresse för de materiella resterna av kejsartidens kulturarv, som enbart representerade njutningslystnad och dekadens.

I Rom där den påvliga aspirationen på politisk hegemoni, under frånvaron av en kommersiellt baserad ekonomi, hade betydligt mer gemensamt med kejsarnas Rom, stod de republikanska ideerna inte högt i kurs. Man kan till exempel jämföra de skilda uppfattningarna om Brutus som tyrannmördare eller ej i Florens och Rom och historien om Michelangelos halvfärdiga Brutusporträtt ${ }^{7}$ är ett fascinerande vittnesmål om detta. Det kunde till och med hända att adelsmän som Stefano Porcari blev förvisade från Rom för sina tal $\mathrm{i}$ Brunis anda om libertas civium, mot varje form av tyranni, i mitten av 1400-talet. Detta kan i viss mån också förklara varför Romhumanisterna avstod från historisktpolitiskt inriktade analyser, beroende som de trots allt var av påvemaktens beskydd. Ritual, ceremoni och mytologiserade historiebilder blev i stället de medel genom vilket det antika kulturarvet skulle återinträda i det allmänna medvetandet och den 20 april 1483 återinfördes den antika romerska seden att fira Palilia (eg Parilia), dvs «födelsedagen» för Roms grundande. Första gången bestod festivalen endast av ett tal av någon ur humanisternas brödraskap följt av en bankett. Men redan 1501, när ceremonin flyttat till Kapitolium, deltog såväl senatorn, Conservatori, och andra civila ämbetsmän, liksom medlemmar av den påvliga kurian. Påvekören sjöng till mässan i Santa Maria in Aracoeli, medan banketten ägde rum i Konservatorspalatset, där musealiseringen av Roms historia redan pågått i några decennier.

\section{PAVARNA SOM MUSEIBYGGARE}

Det är framförallt tre påvar som på olika sätt initierat byggandet av museerna på Kapitolium och utformningen av själva platsen. Det är viktigt att uppmärksamma att detta sker som ett mycket medvetet led $\mathrm{i}$ att ge renovatio Imperii och renovatio Romae ett visuellt uttryck och samtidigt skapa popularitet och prestige åt den vacklande påvemakten. Nicolas $\mathrm{V}$ inleder den verksamhet som skall återge Rom dess forna kejserliga glans genom nya centrala platser där makten och det historiska arvet kan exponeras publikt för medborgarna i en tilltalande form. I första hand satsas på en upprustning av Kapitolium, senare på Vatikanen. Under antiken hade Kapitolium varit en religiös och politisk centralpunkt (Caput Mundi). Där var det viktiga Jupitertemplet uppfört, under vars grund kung Tarquinius en gång hade funnit det caput humanus som gett platsen dess namn och också, enligt de etruskiska prästerna, givit ett tecken om att Rom skulle bli inte bara Italiens utan även världens huvudstad. Kapitolium var också slutmålet för de kejserliga triumftågen. Under medeltiden hade Kapitoliums funktion som symbol för makt och majestät helt gått förlorad. 1200-talskyrkan Santa Maria d'Aracoeli dominerade platsen, vars orientering mot de befolkade delarna av 
8 Rom och bort från Forum Romanum betonades genom att senatorspalatset, säte för Roms kommunala styre och byggt på ruinerna av det gamla romerska statsarkivet, Tabularium, fătt en fasad ut mot den öppna platsen.

År 1447 påbörjade den nytillträdde påven restaureringen av Kapitolium genom att ge Senatorspalatset en förändrad fasad. Fasaden gjordes mer regelbunden med nya stora fönster i piano nobile och genom ett tillägg av en kampanil i centrum fick man en byggnad som mer påminnde om ett norditalienskt castello än ett palazzo communale. Till höger om denna upprustade byggnad lät Nicolas $\mathrm{V}$ konstruera ett nytt stadshus, som gavs namnet Palazzo dei Conservatori - konservatorerna var rådgivare till senatorn. Konservatorspalatset förlades $\mathrm{i}$ sned vinkel ställd mot senatorspalatset och avgränsade på så sätt en piazza på Kapitoliums apex. Det dominerande arkitektoniska temat med stora fönster i piano nobile upprepades även i denna byggnad.

\section{MUSEITANKEN}

Det var detta nya Palazzo Dei Conservatori som år 1471 fick ta emot Sixtus IV:s donation av grekiska och romerska bronser. Bland dessa fanns en hellenistisk skulptur av en pojke som drar ut en törntagg från sin fot; ett romerskt porträtt av en camillus; fragment av en kejserlig figur som inkluderade ett kolossalhuvud och en arm som höll $\mathrm{i}$ en glob; och det kanske viktigaste av allt, den etruskiska varginnan, som födde upp Romulus och Remus och således symboliserade det antika Roms ursprung. Under medeltiden hade dessa bronser stått på antika höga kolon- ner utanför Lateranen. Där hade de haft funktionen att vara moraliserande emblem för den påvliga auktoriteten och för kristendomens triumf över hednisk idoldyrkan. Förflyttningen till Kapitolium befriade dem från dessa medeltida betydelser och deras nya placering överensstämde med Nicolas V:s intentioner att göra denna plats till ett officiellt historiskt centrum. Men de skulle inte enbart beundras som estetiskt inbjudande museiföremål, utan värdet och funktionen som vittnesbörd och testamente för Roms gamla dygder och lysande historia, var ännu viktigare. Detta framgår med all önskvärd tydlighet av den minnestavla som Sixtus lät sätta upp för att celebrera deras återförande till folket $\mathrm{i}$ staden Rom. Denna minnestavla betraktar jag som de kapitolinska museernas stiftelsedokument. Det politiska motivet för handlingen, att Sixtus ville stärka sin prestige och popularitet med hjälp av sin kulturpolitiska manifestation, är skickligt sammanvävt med det legitima intresset för det romerska kulturarvet. Sixtus IV är i övrigt känd som en mycket hårdför och realpolitiskt inriktad påve, vars intresse för välgörenhet eller konst alltid hade ideologiska förtecken. Det centrala i minnestavlans text är att de historiska föremålen återbördas till det romerska folket, som i och med detta skall erinras om sin historia. ${ }^{8}$ Viktigt ur ett museologiskt perspektiv är även att hela Kapitolium och dess byggnader är en allmän plats, vilket är anledningen till att den kapitolinska samlingen blir offentligt tillgänglig redan från början till skillnad från exempelvis Vatikanens samlingar av konst. Flera av bronserna ställdes i själva verket upp utanför palatset, vilket framgår av van Hemskerks teckningar (se bild). Kolossal- 
huvudet och armen som höll i globen var tydliga symboler för Roms universella dominans och varginnan, som placerades ovanför huvudingången till palatset, förkroppsligade den totemistiska makten i Roms majestät. En lång rad fortsatta påvliga tillägg av föremål till samlingen på Kapitolium hade samma syfte - att visa på Roms storhet och historia som påvemakten gärna ville kopplas samman med. Denna mycket tydliga historiska inriktning under 1400-1500-talen övergavs senare under 1600-1800-talen. En förgylld Herkulesbrons i övernaturlig storlek - en figur som för renässansromaren symboliserade dygdens hårda och branta väg, donerades till Kapitolium av Sixtus IV direkt efter upptäckten i Herkulestemplet på Forum Boarium. Senare skänkte påven Leo X marmorrelieferna med Marcus Aurelius fälttåg mot markomannerna tagna från en triumbåge på Forum Romanum och två antika flodgudar, personifikationer av Nilen och Tigris, som kom från ruinerna av Konstantins termer på Quirinalen. Mer direkt relaterad till det antika Kapitoliums politiska betydelse var upptäckten år 1546 av de marmortavlor som listade konsuler och triumfer från den romerska republikens tid. Dessa Fasti Consulares och Triumphales sattes upp på palatsets innerväggar. Intressant är även att Forma Urbis, den antika marmorkartan över Rom, som hade återfunnits och länge ägts av familjen Farnese, nu av opinionen ansågs tillhöra staden Roms borgare och därför överlämnades till de kapitolinska museerna.

I takt med att dessa symboler för romersk triumf, makt och majestät mångdubblades på Kapitolium, avtog dess aktuella roll i det municipala styret av Rom.

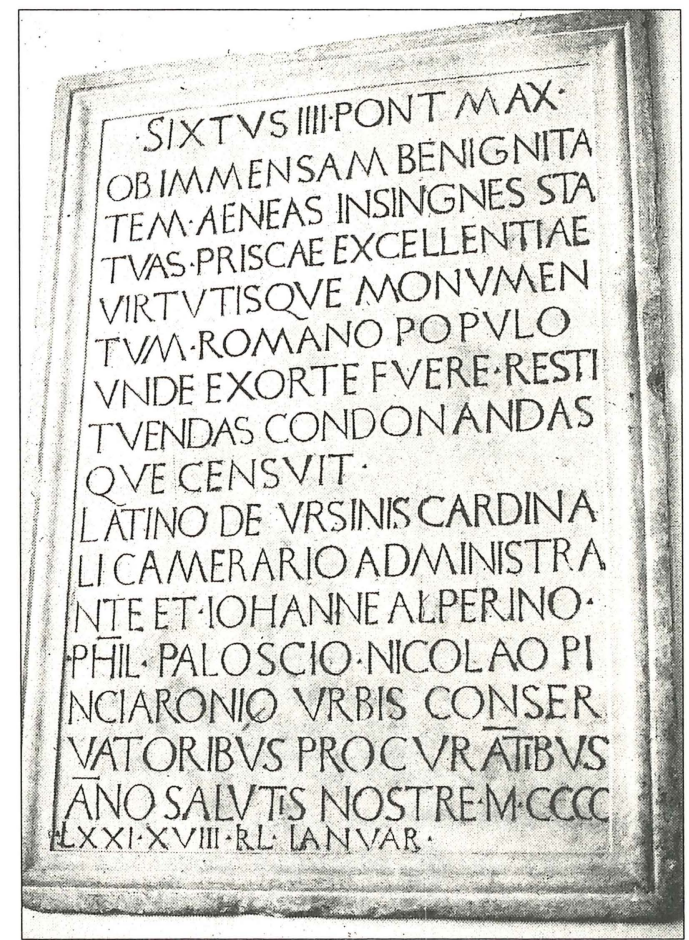

Sixtus IVs minnestavla i konservatorspalatset. (Foto; L. Palmqvist).

En ökande påvlig kontroll över Roms allmänna liv var tydlig redan under Nicolas $\mathrm{V}$ :s pontifikat och konsoliderades under Sixtus IV. Det påvesponsrade återupplivandet av det antika Roms ärofyllda historia annullerade de traditionella medborgerliga friheterna. Transformeringen av Kapitolium från ett säte för kommunalt självstyre till en historisk arena med ett historiskt museum med viktiga monument och föremål från Roms förflutna förstärktes ytterligare under Leo X. År 1514 stipulerade denne att le Conservatori skulle lyssna på föreläsningar i romersk historia före sina möten och tio år senare 
LENNART PALMQVIST

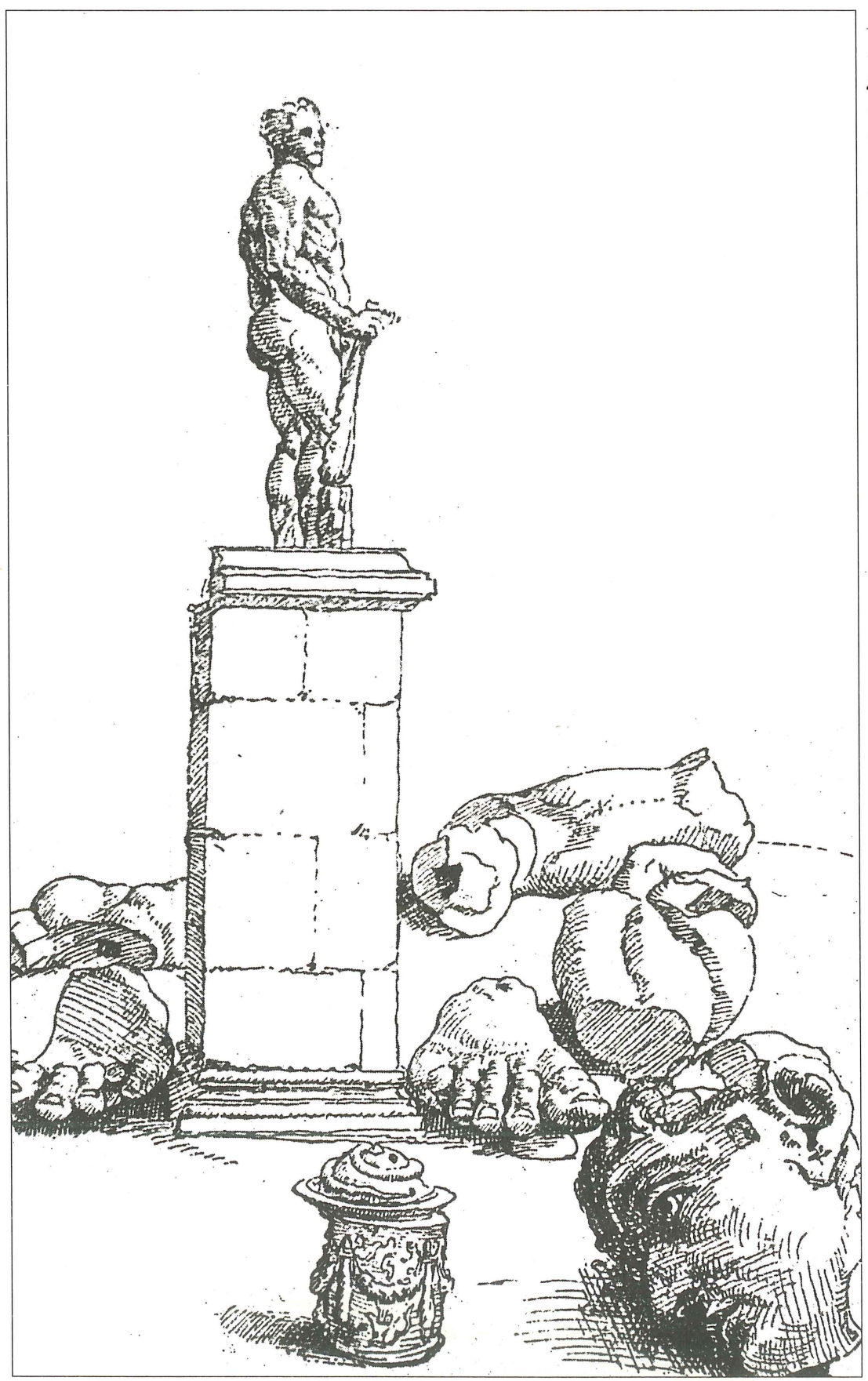

Antika skulpturen pa Konservatorspalatsets gård. Martin van Hemskerk, Römisches Skizzenbuch I, 66v. (Berlin, Kupferstichkabinett). 
planerade Clemens VII ett bibliotek för Konservatorspalatset. Ännu tydligare manifesterades historieintresset genom de stora väggmålningar som utfördes av Jacobo della Ripanda med motiv framförallt tagna ur Livius romerska historia. Mot slutet av Quattrocento fick le Conservatori och andra medlemmar i staden Roms ämbetsmannakår spela roller i de allt fler utbroderade ceremonier som tilldrog sig på Kapitolium för att fira Roms pånyttfödelse. Kommunen Roms tacksamma borgare svarade i sin tur med att beställa en kolossalstaty av Leo X till Kapitolium som var inspirerad av Zeusstatyn i Olympia och Jupiter Capitolinus i salig blandning. I ett berömt tal av Bloisio Palladio var det centrala temat fusionen av den romerska klassiska kulturen med det nya kristna imperiet som regerades av den nye Augustus: påve Leo X.

Som manifest symbol för romersk överhöghet fick Kapitolium sin slutgiltiga form och sin mest långtgående planmässiga utformning genom Paul III:s kulturpolitiska ambitioner och Michelangelos arkitektoniska snille. ${ }^{9}$

Paul III:s första åtgärd var att flytta den förgyllda ryttarstatyn av Marcus Aurelius till Kapitolium. Caballus Constantini som den kallades i folkmun hade under medeltiden stått med de andra bronserna utanför Lateranen. Det första förslaget om en förflyttning till Kapitolium framfördes av konservatorerna år 1498 till påve Alexander VI som ogillade förslaget, starkt påverkad av prästerna i Lateranen. Dessa började nu förstå kulturarvets stora symboliska värde. Paul III var dock fast besluten att genomföra flytten $\mathrm{i}$ avsikt att göra ryttarstatyn till fokuseringspunkt på den nybyggda Piazza del Campidoglio. Miche- langelo beordrades att skapa en ny bas för monumentet och 1539 ställdes den upp mitt på torget. Den stora betydelse som Paul III tillmätte den mer värdiga placeringen av Marcus Aureliusstatyn framgår av en inskrift på en av hans medaljer, där det antyds att sevärdheter av Marcus Aureliusstatyns slag endast låter sig ses på Kapitolium. Statyns allvarliga auktoritet och den välsignelsebringande gesten uttryckte just det fredsbringande budskap som optimus princeps - påve Paul själv gärna ville associeras med. Vidare symboliserade den det romerska imperiets världsöverhöghet, till vilket den romerska kyrkan nu var arvtagare och fullbordade transcendensen med antiken.

Denna ideologiska emfas på kejserlig suveränitet hade accentuerats ytterligare om Paul III kunnat fullfölja sina intentioner att flytta kolossalstatyerna av dioskurerna från Quirinalen. De hade nämligen ännu inte blivit korrekt identifierade utan troddes båda föreställa Alexander den store av Fidias (sic!) respektive Praxiteles. Man anar tanken bakom - Alexander den store-Marcus Aurelius-Paul III, den senare var döpt till Alessandro! Dessutom ville Paul placera en Jupiterstaty $i$ en nisch $i$ Michelangelos trappa direkt i linje med Marcus Aurelius och "Alexandrarna». Men Paul kunde av flera skäl, bland andra utrikespolitiska komplikationer, spanjorernas invasion i Italien, inte fullfölja skulpturprogrammet. Som ersättning för Quirinalkolosserna fick man nöja sig med de dioskurer som hittades i Pompejusteatern och istället för Jupiter hamnade en betydligt mer beskedlig skulptur av gudinnan Roma i trappnischen. Men Pauls planer för den arkitektoniska utformningen av Piazza del Campidoglio kom dock till utförande. 
12 Michelangelo fick uppdraget att ge Kapitoliumplatsen ett värdigt framträdande. Konstnärens förslag är känt genom ett kopparstick av du Perac. Utförandet kom på vissa punkter att avvika från förslaget, men tillkom troligen i huvudsak under Michelangelos arbetsledning. Vad han slutligen skapade var ett trapezoidformat monumentalt stadsrum, vars omkrets anpassades efter de medeltida palatsens läge, vilket ger ett koncentrerat och ordnat, närmast klassicistiskt intryck, och de båda praktfasaderna får en mycket intimare relation till varandra. Det gamla senatspalatset fick en vidgad fasad inklädd i en slät sockelvåning och en piano nobile med kolossalpilastrar mellan fönstren. Det gamla tornet på byggnadens mitt behölls och underströk det symmetriska i kompositionen. Det nybyggda Palazzo Nuovo skapades som en ren spegelbild av Palazzo dei Conservatori och kom senare uteslutande att få funktionen av ett museum. Detta inramade temenos, som var mer som ett rum utan tak än ett stadstorg, fick sin enhetlighet ytterligare understruken av den långa ramptrappan och en skulpursmyckad balustrad. Besökare kom upp till Piazza del Campidoglio som pilgrimer till det eviga Roms symboliska hjässa, caput mundi. Nutida Romresenärer kanske uppfattar Forum Romanum och Palatinen som historiska platser med en starkare koppling till antiken genom den kunskap som frambringats av det senaste århundradets utgrävningar, men från renässansen och lång tid framöver förblev Kapitolium den plats där den romerska medborgaren hämtade inspiration från det förflutna: där fanns kulturarvet materialiserat i historiska föremål och dokument.

\section{KAPITOLIUM}

SOM MUSEUM

När romarna strömmade upp till Kapitolium för att beskåda liket av den unga flickan jag inledningsvis berättade om, var det med nyfikenhet blandad med en förväntan, en förväntan om att få se en autentisk människa från antiken. I vår tid har vi säkert betydligt lättare att föreställa oss hur antikens människor såg ut och hur de levde än man hade under renässansen. Vi har tillgång till flera mycket skickligt gjorda rekonstruktioner. Från Ben Hur och Jag, Claudius till Pompeji-utställningar och annat. Under renässansen var man minst sagt svältfödd på såväl korrekt information som berättande rekonstrutioner av den mytologiserade historien. Det var därför de historiska föremålen väckte ett så stort intresse och Sixtus IV:s initiativ blev en bestående succé.

Vad är det då som konstituerar ett historiskt museum? Enligt min mening behövs det en plats eller byggnad, där man offentligt kan exponera autentiska arkeologiska, historiska föremål eller konstverk som tillhör det egna kulturarvet och som man kan identifiera sig med och därför făr ett kollektivt intresse och värde. Genom att musealisera Kapitolium, eller i varje fall de delar av platsen som var tillgängliga för Roms medborgare, åstadkom man i förlängningen och möjligen delvis oavsiktligt ett historiskt medvetande. Man kan till och med hävda att romarna återfick sin historia och identitet genom att man nu etablerade en tydlig och manifesterad kontinuitet med det förflutna. Enligt min uppfattning inleds denna musealiseringprocess på ett mycket explicit sätt genom Sixtus IV:s försorg redan år 1471, och då 


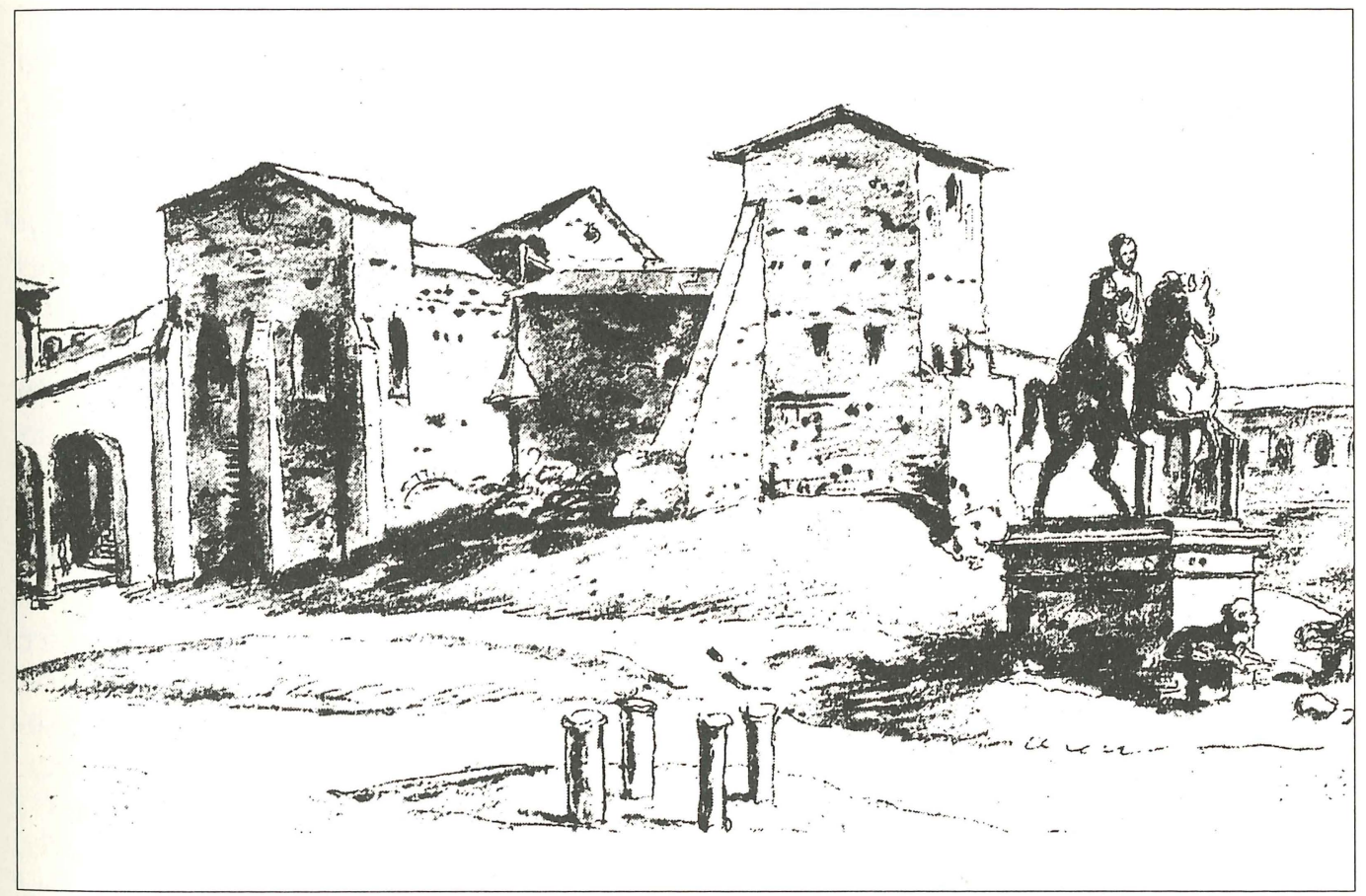

Lateranpalatset med bronsryttaren. Martin van Hemskerk, Berlin Kupferstichkabinett.

är marken redan beredd genom renässanshumanisternas verksamhet.

\section{DET FÖRSTA KONSTMUSEET I FLORENS}

I renässansens Florens saknades förutsättningar för att en byggnad eller en plats skulle få funktionen av ett historiskt museum. Däremot kan man, anser jag, spåra de första ansatserna till ett konsthistoriskt museum i Florens. Min definition på konsthistoriskt museum är då att man, till skillnad från de många ostrukturerade konstsamlingar som fanns i Italien vid denna tid hos furstar och privatpersoner, $\mathrm{i}$ ett museum ordnar upp samlingen på ett systematiskt sätt efter konstteoretiska principer. Man har helt enkelt ett formalistiskt koncept för att dela in samlingen efter till exempel geografiska eller kronologiska aspekter.

År 1586 upplöste sonen och efterföljaren till hertig Cosimo I, Francesco I, sin studiolo i Palazzo Vecchio i Florens och lät flytta över den därvarande samlingen och delar av dekorationssystemet till Tribunan i Uffizierna. Giorgio Vasari hade sedan 1555 lett ombyggnadsarbetena i hela palatset. För gestaltningen av det senast inrättade studiolot (1570), vars funktion snarare var ett samlarrum än en studerkammare, och som speglade en särskild encyklopediskt vetenskapsuppfattning hade en vän till 
14 Vasari, priorn i Ospedale degli Innocenti, Vincenzo Borghini, lämnat konceptet. Grundtanken i det lärda kosmologiska programmet, som också fanns manifesterat i tunnvalvens målningar, var uttrycken för naturlig och konstnärlig skaparkraft.

Likvärdigheten i framställningar av människa och natur skulle tydliggöras, den dåtida vanliga uppfattningen om ett likaberättigande och jämställande av världen i stort som smått, mikro- och makrokosmos. Studiolot tjänade som samling för de mest skilda föremål, som för det mesta bevarades i därför avsedda vägghyllor. Därutöver fanns det 34 målningar upphängda i dubbla rader, och åtta bronsstatyetter i nischer. Eftersom naturlig belysning saknades (det fanns endast ett fönster som var täckt av en målning) var föremålens synlighet relativt begränsad. ${ }^{10}$ I Uffiziernas tribuna blev förutsättningarna helt andra. Vasari hade själv gjort ritningarna för den mäktigaste offentliga byggnaden i 1500-talets Florens. Efter hans död 1574, öveîtog Bernardo Buontalenti ledningen för arbetet med den jättelika kontorsbyggnaden. Kort efter byggnadens färdigställande (1581) lät storhertig Francesco stänga övervåningens loggia för att omvandla denna till ett galleri, till en gång smyckad med grotesk-ornamentik där konstverk ur Medicisamlingen ställdes ut. Där byggdes 1584 tribunan, troligen det första arkitektoniskt gestaltade rum som byggts $i$ avsikt att fungera som ett museum för konst och naturalier. Det åttakantiga kupoltäckta centralrummet fick sin belysning genom överljuset från åtta fönster i kupolansatsen. Hit fördes således delar av samlingen från den tidigare studioloinredningen i Palazzo Vecchio. Detta rum var klätt med röd sammet och ett runt konsolstött bord som innehöll skjutlådor från tolv ädikulor löpte runt väggarna $\mathrm{i}$ ögonhöjd. Denna inramning utgjorde samtidigt presentationen. I mitten stod ett träskåp där man förvarade småkonst, rariteter och naturalia. Övriga föremål förvarades i lådorna i det kringlöpande bordet. I hörnen av rummet stod åtta antika marmorskulpturer och på väggarna hängde tavlor av de viktigaste italienska samtida mästarna (1500-talets första hälft). Ett inventarium från 1589 nämner till exempel verk av Rafael, Andrea del Sarto, Bronzino, Parmigianino, Pontormo och Giorgione. ${ }^{11}$

Med sitt utställningskoncept står Uffiziernas tribuna i skärningspunkten mellan två system, dels de bevarade elementen från studiolo/Wunderkammer atmosfären, som även kom till uttryck i kupolens ikonografi, dels konstsamlingens framträdande position i rummet som pekade framåt i tiden och föregick 1700-talets museer. Tribunan blev till ett rum för samlingens praktstycken där antika och samtida mästerverk fick den kongeniala inramning som de konsthistoriskt förtjänade. Det är uppenbart att det stod klart för konsthistorikern Vasari att en konstsamling förutom det rent estetiska värdet kunde användas $\mathrm{i}$ ett klassificerande syfte och att själva musealiseringen var nödvändig för att nå fram till en förståelse av samtidskonsten. Litet tillspetsat kan man kanske påstå att konstmuseerna är nödvändiga för konstvetenskapen, och att Vasaris koncept skapade en utgångspunkt och en grundläggande förutsättning för alla senare konstmuseer. Enligt min uppfattning är det fullt möjligt att Uffiziernas tribuna stått modell för flera av 1700-talets privatmuseer vid furstehusen i Europa som till exempel den första självständiga konstmuseibyggnaden på kontinenten, Fridericianum i Kassel, 
grundlagt av Friedrich II av Hessen och öppnat år 1779 .

Om tribunan kunde ses som centrum för sammanhanget så grupperade sig gallerirummen sedan i en U-formad grundplan där, vid sidan av andra konstföremål även kopior av de uomini illustri som fanns i original i Paolo Giovios musaeum i Como sattes upp1212. En väg genom konst och historia börjar skönjas här. I den berömda Corridoio, där Vasari förbinder Palazzo Vecchio med Palazzo Pitti, som sedan får en genial förlängning genom Uffiziernas övervåning, för att sluta i Pittipalatsets teatraliskt utformade Boboliträdgård. Från den politiska sfären, furstarnas regeringssäte, till konst och därifrån via ett sakralt område (hovkyrkan Santa Felicitá) kunde man sluligen nå fram ända till naturen, med museet som knutpunkt. Här förebådas, dock i en annorlunda konceptionell kontext, redan en reflex av det som museerna från slutet av 1700-talet visar i ett estetiskt-historiskt åskådliggörande av konsthistoriens bilder. Trots att flera personer varit inblandade i skapandet av detta tidiga konstmuseum står det utom varje tvivel att Giorgio Vasari såväl genom sin gestaltning av museidelarna av Uffizierna som genom sitt livsverk Libro dédisegnisom kan liknas vid ett konstmuseum i bokform - skapat förutsättningarna för att museitanken sedan utvecklas $\mathrm{i}$ all vidare cirklar runt om i Europa och att den gryende konstvetenskapen blir den vetenskap som verkar i pådrivande riktning.

De båda exemplen från Rom och Florens visar att det inte endast var i de många naturvetenskapligt inrättade samlingarna som Italien varit ett föregångsland i den europeiska museihistorien.
NOTER

1. Ludwig von Pastor, Storia dei Papi dalla fine del Medio Eve, Rom 1912, III, 244-245.

2. Edward Alexander, Museums in Motion. An Introduction to the History and Functions of Museums. Nashville 1979, 81, daterar det första historiska museet till 1837 i Versaille.

Humanisternas strävanden finns väl sammanfattade i Charles L. Stinger, The Renaissance i Rome. 1985.

3. Rudolfo Lanciani, Storia degli scavi di Roma e notizie intorno le collezioni romani di antichità. 4 vol. Rom 1902, 1, 166. För breven se originaltexten i V. Golzio, Raffaello nei documenti, nelle testimonianze dei contemporanei e nella letteratura del suo secolo. 1936, 33-38.

4. Om Gian Francisco Poggio Bracciolini (13801459) kan man med behållning läsa i Ernst Walser, Poggio Florentinus' Leben und Werke. Leipzig 1914. Den förste som i större omfattning skrev av romerska inskrifter och använde sig av dem var dock den romerske statsmannen och humanisten Cola di Rienzo (1313-1354), som författade den första beskrivningen av staden Rom omkring år 1344.

5. Framställd som ett tempel ännu på Fazio degli Ubertis illustration till poemet Dittamondo i ett 1400-tals manuskript. (Se bild i Schnapp 1993, 120).

6. Se särskilt Macchiavellis analys av Livius i

Discorsi sulla prima deca di tito Livio från 15131521, som tillsammans med Principe, inledde en ny fas i renässansens politiska tänkande.

Leonardo Bruni hade redan 1403 i sin Laudatio Florentinae Urbis betraktat Florens historia ur perspektivet «libertas rei publicae».

7. Den förre statssekreteraren i Florens, Donato Giannotti, gav, när han trädde i tjänst hos kardinal Ridolfi, Michelangelo i uppdrag att utföra en byst av Brutus och Michelangelo börjar på ett porträtt som visar en vacker, självsäker och 
aggressiv tyrannmördare, men lämnar sitt arbete ofärdigt. En efterlämnad dialog skriven av Giannotti, där de båda diskuterar Dantes behandling av Brutus, visar att Michelangelo inte var övertygad om att mordet på Caesar berättigat. I Rom hyllades Caesar under renässansen, medan det republikanska Florens hyllade "tyrannmördaren» Brutus.

8. Texten på minnestavlan lyder: SIXTUS IIII. PONT.MAX.OB IMMENSAM BENIGNITATEM AENEAS INSIGNES STATUAM PRISCAE EXCELLENTIAE VIRTUTISQUE MONUMENTUM ROMANO POPULO UNDE EXORTAE FUERE RESTITUENDAS CONDONANDASQUE CENSUIT..... För en utförligt tolkning av tavlans text se T. Buddensieg, 'Die Statuenstiftung Sixtus' IV im Jahre 1471. Von den heidnischen Götzenbildern am Lateran zu den Ruhmezeichen des römischen Volkes auf dem Kapitol.' Römisches Jabrbuch für Kunstgeschichte 20, 1983, 34-73.

9. Beträffande Michelangelo se, A. Morrogh, 'The Palace of the Roman People: Michelangelo at the Palazzo dei Conservatori.' Römisches Jabrbuch der Biblioteca Herziana 29, 1994, 129-186.

10. W. Liebenwein, Studiolo. Die Entstehung eines Raumtyps und seine Entwicklung bis um 1600. (Frankfurter Forschungen zur Kunst 6.) Berlin 1977.

11. A. Gotti, Le Gallerie di Firenze. Florens 1872.

12. Kardinalen och biskopen i Como, Paolo Giovio (1453-1552) var möjligen den som först använde ordet musaeum för sin porträttsamling av berömda män i sin lantvilla vid Comosjön. Samlingen bestod av flera hundra porträtt, bl a verk av Mantegna, Bellini, Rafael Tizian. Giovio ordnade dessa porträtt kronologiskt med små kortbiografier (Elogia).

\section{SUMMARY}

The first Renaissance Museums in Rome and Florence

This paper argues that the archaeological and antiquarian research by the Renaissance humanists in
Rome inspired Pope Sixtus IV to donate a collection of ancient bronzes from the Lateran to the Capitol in 1471. This led to the start of the musealization of the Capitol which culminated in the forming of a historical museum at the Palazzo dei Conservatori during Paul III's pontificate in the 1530s. Paul III's plan for the renewal of the Capitol included the transfer to the Capitoline Hill of the equestrian monument of Marcus Aurelius from the Lateran as well as Michelangelo's new design for the buildings and the piazza. The public forum of the Capitol with its display of historical sculpture and other objects of authenticity conveyed a symbolic content, relating to Rome's historic past, and thus evoked a variety of positive meanings for the future of the city. It is further argued that the Palazzo dei Conservatori on the Capitoline Hill was transformed from a municipal government building to a historical museum through highly concious political enactments by some of the Renaissance popes.

In Florence the musealization during the Renaissance took another direction due to a different political and social situation. Vasari's role in forming a concept for the future art museums in Europe has not previously been observed. In a short concluding note the article underlines that the achievements and influence of the talented Vasari also included principles for the displaying of art in gallery/ museum expositions. The debt to Vasari, in the formalization of art collections in the early museums of Europe, should be acknowledged and evaluated.

Lennart Palmqvist är klassisk arkeolog och leder den akademiska utbildningen i museikunskap vid Stockholms universitet.

Adr. Historiska institutionen, Stockholms universitet, S-10691 Stockholm

Email: lennart.palmqvist@historia su.se 